discussion, which ran for some months and in general proved to be critical of the current emphasis on mathematics as such. One correspondent depicted a future with a computer on every classroom desk and suggested that with the advent of the computer as "co-respondent", the long "marriage" of mathematics and science was ripe for divorce.

Professor M. Evgrafov, of the Mathematics Institute of the Academy of Sciences went further. "Not a single result" in pure mathematics, he claimed, had had any practical application for the past fifty years, and the current insistence on a mathematical training for scientists was "wanton", "rigid" and "useless". In the future, he said, problem-solving will be increasingly left to programmers whom he described as "persons of middle-level qualifications".

In 1980, Pontryagin shifted the whole debate from the educational and cultural journals to Kommunist, the leading Party theoretical monthly. His criticisms thus took on the force of tacit party policy, and have undoubtedly played a part in shaping the revised syllabus, which will give greater emphasis to practical applications and seems designed to train the "middle level" technicians of whom Evgrafov spoke.

The signs are that the new syllabus will downgrade set theory (except, optionally, in geometry), eliminate "difficult" terminology and symbolism and play down theoretical precision in favour of an "intuitive and descriptive" approach with an emphasis on new mathematical technology, including computers. Vera Rich

\section{British Antarctic Survey A good wind}

On the principle that "it's an ill wind ...", the British Antarctic Survey is hoping that the war over the Falkland Islands will bring back good times again. Meanwhile, the survey is congratulating itself that those of its scientists left stranded on South Georgia after the occupation by Argentine forces have made good use of their extra six weeks on the island.

The supply vessel that would normally have picked up the scientific parties from South Georgia in April, the RRS Bransfield, also seems to have done useful work. The ship was apparently in the Chilean port of Puerto Arenas at the occupation of the Falkland Islands, collecting spares for diesel engines and other gear. In the succeeding weeks, it was able to monitor radio transmissions between Port Stanley, on the Falkland Islands, and the mainland of Argentina.

During the ship's spell in Antarctic waters (below 60 degrees south), the ship served as a relay station between the British bases in Antarctica, and even kept in touch with those isolated on South Georgia by means of relayed signals from the base at Signey one the South Orkney Islands.

\section{Falkland minerals}

An agreement of sorts between Argentina and the United Kingdom on the title to submarine mineral rights off the Falkland Islands appears to have been reached on the eve of the occupation of the islands, and to have been embodied at the end of April in a resolution of the United Nations conference on the Law of the Sea. The resolution adopted by the conference (but with Argentina's dissent) says that where there are disputes about the sovereignty of territories (such as the Falkland Islands), mineral resources shall be exploited as if the wishes of the inhabitants were paramount.

This resolution appears to be a compromise reached after the rejection by Western powers, France and the United Kingdom in particular, of a draft article of the treaty that would have given each disputing party an effective veto on mineral exploitation, and which used the weaker form of words "for the benefit of the inhabitants".

The rejected article of the treaty, described as "anti-colonialist", would also have given the United Nations an important role to play in the regulation of disputed marine mineral rights. The resolution eventually adopted by the conference, which will not have the force of international law, plainly suits the British book much better.

Normally, communications with the British Antarctic bases are relayed to Cambridge, England, through the radio and telex station at Port Stanley, out of action since early April.

For most of the Antarctic programme, the interruption caused by the Falklands war should be small, as most of the bases were resupplied just before the occupation of the Falklands. On South Georgia, however, where there has been a weather station in continous operation since 1944 and more recently a summer biological station on Bird Island nearby, a season's work is likely to be lost.

Apart from the difficulties of operating its two ancient ships in hostile waters, most of the British Antarctic Survey's problems are monetary. The numbers of people on its books have been shrinking for the past decade, and now amount to about 300 , of whom 120 are scientists. The budget for the current year is about $£ 6$ million, a modest decline compared with the previous year without allowing for inflation. Even so, it has been possible to rebuild two of the three bases on the Antarctic Peninsula, while there is an ambitious plan to rebuild the base at Halley, on the Weddell Sea.

What the survey now hopes is that the British government's renewed interest in the South Atlantic, and the practical need to find peaceful activities that will occupy British nationals there, will prompt morc generous budgets.
Chinese census

First head-count begins next week

\section{Experts applaud revised plan}

\section{Washington}

The only modern census of China's estimated 1,000 million people, who make up one-quarter to one-fifth of the world's population, will take place on 1 July. China's last census was in 1964, but Western demographers consider its results suspect. The earlier count in 1953 is similarly in doubt. So the July count is a demographic event of major historical proportions.

At the 1953 census, Mao Tse-Tung officially governed $583,603,417$ people. The number was growing rapidly in accordance with Chinese family customs and Mao's dictum of 1949 that "revolution plus production can solve the problem of feeding the population ... Of all things in the world, people are the most precious . .". But by 1957 , the net increase was 20 people per thousand per year and the official line changed. Mao said the population should be stabilized, perhaps at 600 million people.

That figure had probably already been exceeded and subsequent famines, political upheavals and other changing conditions have increased uncertainty as to how many people China has. Age, sex and regional breakdowns are critical for its centralized state planning. But an accurate count, besides helping the government, will among other things show whether the government's past claims for success in population control are true.

But the scale of the enterprise is staggering. How do you count 1,000 million people? Previous censuses in China were carried out literally with hand tabulation and abacuses. For the 1982 census, the government has acquired 20 IBM $4331 \mathrm{E}$ Series computers and one IBM 4341 computer with funds from the United Nations Fund for Population Activities (UNPA), and has bought eight Wang computers on its own.

The five million or so enumerators will be office workers, staff of local institutions, rural accountants and record keepers. In a test count in the county of Wuxi, enumerators were required to have at least a junior middle school education. The census forms will have 19 categories to fill in, some by code, some by ordinary writing. (The 1964 census form had eight categories; the 1953 census had five). Representatives of each household will be summoned to registration points to tell the enumerators how many people were in the household at midnight, 1 July. Or they will be reached by mail, or visited on their 